\title{
On the Ontological Concept of "Sexual Difference": A Material, Dynamic, and Synthetic Approach
}

\author{
María J. Binetti \\ CONICET, Buenos Aires University, AR
}

\begin{abstract}
BINETTI, J. M.: On the Ontological Concept of „Sexual Difference“: A Material, Dynamic, and Synthetic Approach.

Philosophica Critica, vol. 6, 2020, no. 1, ISSN 1339-8970, pp. 19-35

Men and women are sexually different, and the differences matter. However, such differences have little to do with the dualism of gender stereotypes, the power hierarchies of patriarchy, or the biological determinism of two opposite and exclusive sexes. How to understand the sexual difference then? This paper aims at answering the question from the framework of a material realism that has overcome the dualism of difference as well as the biological reductivism of sexuality.
\end{abstract}

Key words: Feminist theory - Gender - Embodiment - Realism Plasticity

\section{Introduction}

At first sight, the question of sexual difference appears to be a self-evident and immediate fact, key reason of both patriarchal domination and women's struggles. The sexual difference between men and women has been the conceptual tenet for feminist theory, the subject of women social emancipation, the criterion for statistical analysis and the basis of women's civil rights. However, the immediate evidence of sexual difference fades away as soon as one intends reflecting on it and accounts for its internal consistency. Is sexual difference a merely biological fact or just a cultural construction? Does it represent a discursive fiction, an immutable essence, an accidental determination? Is it intrinsically material or extrinsically materialized by language? The possible answers are multiple and diverse, but whatever they might be, the question of sexual difference remains inevitable (Irigaray 1993; Grosz 2011; Braidotti 1994, 2002). 
Currently, the question of sexual difference arises with renewed interest for a number of reasons. First, and from a negative side, because of queer theories insistence on the discursive character of sexuality, reducible to a normative fiction within the limits of a relativist, antirealist and sociolinguistic framework (Butler 1993, 1999, 2004; Preciado 2003). On the other side, the reduction of sexual difference to discursive practices boosted the rise of a new material and ontological trend, determined to rethink sexuality as the immanent and creative dynamism of matter itself (Gatens 1996; Alaimo - Hekman 2008; Coole - Frost 2010; Dolphijn - van der Tuin 2012). From another perspective, evolutionary psychology and psychoanalysis have claimed for a proper approach to sexual difference, irreducible to biological or cultural views, although entangled with them (Irigaray 1985a; Buss - Malamuth 1996; Copjec 2002; Zupančič 2017). Lastly, also natural sciences have recently questioned the epistemic usefulness of gender category understood as the sociocultural interpretation of a merely biological sexual difference (Jordan-Young 2010; Bluhm - Jacobson - Maibom 2012).

In such a context, the present article aims at approaching the question of sexual difference from an ontological perspective, dialectical and dynamic, outside dualism of the difference as well as the biological or cultural reduction of sexuality. I will intent to explain why difference is a complex and heterogeneous self-differing movement that opens multiple fields of existence. In the same sense, I will attempt to justify that sexuality encompasses a plural reality, made up of biological, psychic, cultural, and personal energies. Ultimately, I will try to show that a material, dynamic, and synthetic concept of sexual difference is richer and more productive than the rigid dualism between a biological sex and a cultural gender.

\section{Conceiving the "Concept" of Sexual Difference}

I assume sexual difference is a concept, and this supposes a precise ontological meaning. Namely, it means sexual difference is not a formal and fix representation produced by the understanding ability to abstract and generalize from the particular, but a concrete action of conceiving, cause and effect of its own differing. Put differently, I assume the concept as the immanent development of reality following Hegel's definition of concept as "the innermost moment of the objects, their simple life pulse" (Hegel 2010, 17), their "immanent motion or self-movement" (Hegel 1979, 26). Like the vital pulse of a living organism, concept is everywhere, invades everything and retains an "absolute power" that "lets its difference go free" (Hegel 2010, 536). In more recent terms, authors like Gilles Deleuze, Félix Guattari or Elizabeth Grosz defines concepts as "centers of 
vibrations" (Grosz 2011, 79; Deleuze - Guattari 1994), affective mediums and measures of vital energies.

While universal representations discriminate, fix and define the formal content of abstract understanding, concepts open reality to its immanent activity and unfold their inherent forces, what implies a double or dialectical movement of negation and affirmation, destruction and creation at once, in order to maintain deploying the effective actuality. Therefore, concepts are never immediate, straightforward or fixed forms, but always mediate and complex self-movements that open the space, time and history of its own unfolding. Briefly, they are their own continual differing. When authors like Hegel, Deleuze, Guattari assign to philosophy the task of producing concepts (Deleuze - Guattari 1994, 36 ), they mean the ontological identity of being and thought, theory and praxis, capable of producing a new order of things. And such is, to my mind, the conceptual meaning of sexual difference.

To assume sexual difference as a concept intends to account for the subjective and complex becoming of each singular individual, whose sexual identity is irreducible to mere gendered stereotypes or social roles, as well as to simple biological functions. As inherent dynamism, sexual difference concretely means self-differing, that is, an always changeable, multiple and heterogeneous existence. That is because the difference meant by the concept supposes for a negative and indeterminate instance that makes possible the continual transformation of the subject. The dynamism of sexual difference contains an indeterminate and negative force, condition for its permanent differing. At this regard, Elizabeth Grosz has asserted that "the ontological status of sexual difference implies a fundamental indeterminacy such that it must explain its openness, its incompleteness, and its possibilities of being completed, supplemented, by a (later) reordering" (Grosz 1995, 80). Differing from such a virtual openness to new determinations constitutes the self-movement of the concept, its particular and singular way of becoming a sexed individual.

Whereas the dualism of two opposed sexes represented by abstract generalizations compels sexual difference to fit into hierarchical and unequal stereotypes, instead the historical progress of feminist theory has released the creative potential of sexual difference. That is why Iris van de Tuin considers it as "a hyperinternalistic or immanent affair, the most basic, ergo, the most virtual of feminist objects and tools" (van de Tuin 2014, 69). From a conceptual point of view, sexual difference is the breaking point of patriarchal hegemony as well as the keystone of feminism as philosophy. In Claire Colebrook words, it is that concept that opens the conceptuality of concepts (Alaimo - Hekman 2008, 78), namely the only self-movement able to disrupt the patriarchal hierarchy of sexes to set in motion their free differing. 
In the context of feminist thought, it was Luce Irigaray who introduced sexual difference as an ontological category, out of both patriarchal dualism and linguistic constructivism. Irigaray converted sexual difference from a mere representation to a proper concept. Nowadays, under the umbrella of the third wave and the demise of postmodern constructivism (Dolphijn - van der Tuin 2012, 25), reconsidering sexual difference as a strategic concept of feminism is a way of reaffirming the transgenerational continuity of feminist thinking. If sexual difference is a historical and multiple differing, instead of a sum of abstract representations, then continuing to think it is an urgent task.

Summing up, the concept of sexual difference implies the self-movement of a living subject, unstable and fragile, fraught with contradictions, self-negations and uncertainties. Accordingly, some authors prefer to talk of active sexual differing - rather than a fixed difference - in order to express the radical dynamism of sexed subjects.

\section{Sexual Difference as Ontological Differing}

Although sexual difference has been a basic tenet of feminist thought and praxis, it was Luce Irigaray who properly turned it into an ontological concept, key category for philosophy in general and for feminist philosophy in particular. According to her, the history of philosophy ignored the question of sexual difference to the extent that it interpreted the whole existence according to a phallic-homo-logic, the logic of the One and Same. Male sex has been indeed the only one Subject, criterion and measure of human existence, while female sex became the subaltern other: a degraded and imperfect copy of him. Phalliclogic relegated women to the realm of unreal and impossible, a passive container of virile actions. Irigaray restored sexual difference into the core of being as its immanent movement, turning it into "one of the major issues, if not the issue, of our age" (Irigaray 1993, 5). The feminist issue of sexual differing is not about adding women to patriarchal structures, but rather about transforming them into other logic. The relevance of sexual difference as a "philosophical concept" (Grosz 2011, 103, 144) is just this radical potential to amend the assumptions of thinking. In what follows, I will attempt to focus on such distinct ontology.

At first, that what turns difference into a concept - instead of a fix and abstract representation - lies in the immanent dynamism of identity from itself to itself, a self-reflected movement capable of negating and redetermining its own identity (Grosz 2011, 93; Stone 2002, 16). In order to self-differ, identity must contain a twofold motion at once negative and affirmative, identical and not-identical, that is, transformative. This twofold motion defines the conceptive movement of difference, also described as a "generative force" (Grosz 2011,94 ), able to open multiple ways of being and becoming. 
Ontology of sexual difference might be regarded as a "virtual" one (Colebrook - Buchanan 2000, 228; Braidotti 2002, 7), meaning by virtuality the inner potency to be and become. Virtual power represents another name for the fundamental indeterminacy aforementioned by Grosz (Grosz 1995, 80), whose negativity remains in constant redefinition. Remaining open to a virtual and possible becoming implies an always uncertain future, whose evolving contingencies and particularities are unpredictable. In this regard, Iris van de Tuin comments that "sexual differing is always already virtually at work for feminist futures and therefore has the greatest potential for the generation of these futures" (van de Tuin 2014, 69). Accordingly, the concept of virtuality is constitutive of a dynamic differing and involves the energy for a regenerative project.

The negative and virtual character of self-differing - in contrast to the abstract and immediate character of mere identity - has been also determined by the principle of "not-one" or "not-all" as a radical deconstruction of what is simple-one. In the context of sexual difference, to be "not-one" and "not-all" means that "neither you nor I are the whole nor the same, the principle of totalization" (Irigaray 1996, 105), because there is always a gap, a failure, "a lack at the very heart of sex or, more precisely, it concerns sex as the very structural incompleteness of being" (Zupančič 2017, 141-2). Thinkers of sexual difference such as Irigaray, Jacques Lacan, Slavoj Žižek, Alenka Zupančič, Rosi Braidotti or Joan Copjec, among others, read the difference in terms of an ontological gap that breaks and passes through the core of any sex, always dialectically other. Ontologically speaking, "not" is at the beginning of all one as the virtual and negative force by which becoming. Such primordial differing is - says Žižek - "that of woman and Void (or death: das Mädchen und der Tod)" (Žižek $2016,11)$. Woman-void, woman-other, not-woman of woman-difference express a sort of ontological identity crossed by the other.

Female differing expresses that particular potency able to become two subjects so that the dialectical principle of not-one and not-all turns out to be the relational principle of "being-two". In respect of the abstract and simple homo-logic of One Subject, the hetero-logic of differing boosts the creative economy of being-two (Irigaray 2000, 141 ff.): a kind of two between which there is neither dualism nor fusion, but relational unity. The "being-two" of differing means duality without dualism, to the extent that it subsists in the immanent dynamism of not-one, instead of one abstract individual extrinsically related to another one. Being-two expresses the relational constitution of no-one, whose incompleteness makes room to the other. In this regard, Alain Badiou names female identity as "a passage of between-the-Two" (Badiou 2017, 94), a process rather than a position, a mediating dynamism rather than an addition of ones. 
According to Irigaray, being-two comprises the ontological category for a relational and reciprocal not-one inevitable involved with another. Indeed, subjective relationships can be said in many ways and respects, but all of them involve an inner movement that incomplete and expand the simple one. When Irigaray claims that "the universal is two" (Irigaray 2000, 29), so that sexual difference constitutes "the most appropriate content for the universal" (Irigaray 1996, 47), she radically deconstructs the homo-logical ideal of Identity in order to assert the immanent negativity of all one. The universal is two not because it is two substantial things, but because it is dynamically not-all and continually other, its own self-differing.

Ontologically speaking, the concept of sexual difference can be reduced neither to the difference between man and woman - as if there were two opposite and simple substances - nor to the hetero-normative linguistic fiction of bio-political regime - like Michel Foucault, Judith Butler or Paul-Beatriz Preciado interpret it. Both alternatives coincide with the dualistic and phallogocentric representation of difference as two opposites ones. By contrast, out of substantialism and constructivism, sexual difference expresses the self-reflective, negative and relational dynamism by which the finite and incomplete no-one reaches itself. The negative and reflective structure of self-differing opens up the possibility of multiple, heterogeneous and changeable sexual determinations, coming from its own indeterminacy. It can be stated, therefore, that sexuality implies assemblages of minimal differences, intensities, elements, choices, etc. in constant transpositions.

Briefly, conceiving sexual difference in the pattern of a self-differing identity let the immanent potency of identity be free, other, double, two, multiple, heterogeneous. Such dynamic conception characterizes feminisms of sexual difference, for which women never are simply one but always plural and fluid (Irigaray 1985b, 26, 28, 106 ff.), nomadic (Braidotti 1994), volatile (Grosz 1994), generative and relational subjects (Battersby 1998). Instead of a masculine, active and determinant One confronted with a female, passive and receptive other, sexual difference puts in motion the otherness into the one.

\section{A Material, Embodied and Embedded Differing}

Sexual difference remains a material reality, embodied and embedded in the flesh. Inasmuch as it comprises a dynamic and active process, then the representation of sex as an immutable identity characterized by fixed properties should be abandoned. On the contrary, conceptually assumed, sexual difference expresses the movement of matter itself, its reflective unfolding. The idea of a matter actively self-determined overcomes the traditional hylomorphism by new material perspectives. In fact, according to hylomorphic theory, matter 
opposes to form as the passive, obscure and amorphous substratum to the active, rational and determinant cause; it represents an empty recipient of perfect actions. However, according to new material ontologies, matter remains active and autopoietic energy that, following Manuel de Landa, "has morphogenetic capacities and does not need to be commanded into generating form" (Dolphijn - van der Tuin 2012,33). It involves an active potency capable of producing its own sexual differing.

New material perspectives are distinguished from vulgar and mechanist materialism as well as from historical-dialectical materialism. They propose a kind of matter fractured by negativity, otherness, incompleteness, whose ontological formula turns out to be, in Žižek's terms, "not-All is matter" (Žižek 2006, 168). Against positivist materialisms, for which all is matter and material entities are simply all and ones, new ontological perspectives consider material beings are always fractured, contradicted and tensioned by opposite forces. Even more, the immanent negativity of matter produces immaterial phenomena like conscience, affectivity, freedom, culture.

Because matter is not-all, it constantly differs from itself, becoming at a time inner energy and external surface. On the one hand, matter is "inside", the "interiority" of any sensation, perception, memory, consciousness, unconsciousness, etc. (Nancy 1993, 191-192; Alaimo - Hekman 2008, 71). At this regard, sexual difference constitutes a "hyperinternalistic" issue (van der Tuin $2014,69)$, subject of any affect, idea, representation, desire, etc. On the other hand, matter is "outside" (Nancy 1993, 192), the exteriority of all sensation, perception, memory, consciousness, etc., that is, their object. Simultaneously, material dynamism exposes pars extra pars while internalizing them into consciousness.

Matter distinguishes parts extra/intra parts, and synthesizes them in dynamic and relational organizations, qualitatively more than the mere juxtaposition of its elements. New materialisms have named that sort of dynamic organization "assemblage" (Gratton 2014, 122-123; Žižek 2017, 40): a key category that overcomes the abstract order of self-identical substances by the synthetic order of self-differential realities, composed by heterogeneous agencies, material and not-material, human and nonhuman, natural and cultural. Another category introduced by new materialism is "plasticity" (Malabou 2005, 186): an alternative name for a self-differing matter. Plasticity expresses the capacity of matter to move from its negative indeterminacy to an unpredictable, contingent and accidental determination. A plastic matter contains both virtual indeterminacy and actual determination in reciprocal exchange and continual becoming. Categories like assemblage, plasticity, indeterminacy, complexity or unpredictability allow material ontologies to work in tune with scientific disciplines such as quantum physics, neurosciences, and genetics. 
In this ontological context, sexual difference emerges as a material event, result of non-linear, complex, unstable, entangled and contingent energies. From the point of view of new materialisms and material feminisms, matter is constitutively sexed inasmuch as it remains differing, virtual and never simply one. Sex is not an external form that comes from without upon matter as if it were a passive and receptive substrate waiting for an active determination. Contrary, sex is the proper dynamism of matter itself, its immanent act of mattering. Conceived as a process, sexual difference expresses the synthesis of multiple pars, layers, and intensities in continual becoming. While "gender" represents a socio-linguistic category that aims at making visible the cultural construction of biological sexes, sexual difference instead points out a transversal differing immanent to multiple energies, biological and cultural, subjective and objective, internal and external. In other terms, sexual difference encompasses biological, psychological, historical, cultural and existential instances. What follows intends to approach such entanglement of sex.

Biologically speaking, sexual difference brings into play multiple factors integrated by complex mechanisms changing all throughout life. The determination of sex constitutes itself a sequential process that starts at the genetic level and ends in the establishment of the gonads, ovaries, and testicles. It is followed by sex differentiation, which includes the development of phenotypic structures such as internal and external genitalia. Sexual determination and differentiation processes are not reducible to the reproductive tract but involve the whole body. "Every cell has a sex" (Wizemann - Pardue 2001, 4), precisely each one of the 10 trillion cells that make up the human body is determined by the same 23 pairs of chromosomes and all of the DNA information. Then, the dimorphic structure in the 23rd pair of chromosomes - XX or XY for all mammals - operates at any level of body organization. Rosi Braidotti comments that sexual difference is "encrypted in the flesh, like a primordial memory, a genetic-data bank that pre-dates entry into linguistic representation" (Braidotti $2002,46)$. Accordingly, genetic sexuality is, at least by now, indelible no matter how culturally it is expressed or classified, it is readable under all historical and contingent representations.

The dimorphic structure of the human genome comprises an assemblage of about 30,000 genes and 3 billion of base pairs of DNA, of which about the $5 \%$ corresponds to sex chromosomes. Instead of immutable and fix, they compose epigenetic mosaics and overlaps (Wizemann - Pardue 2002, 36, 85) signed by variation, interactions, and transpositions. Luciana Parisi describes it as a genetic entanglement of micro particle-forces in permanent tension and movement (Parisi 2004, 32). Not only biological but also cultural and psychosocial factors interact with genetic elements. The sexual genotype implies behavioral, perceptive and cognitive differences depending on brain areas and 
functions; hormonal differences can equally affect gen expressions or conducts throughout life. Just an example, testosterone is related to aggressiveness and social dominance, while estrogen has to do with mood changes.

From an evolutionary point of view, sexual difference is a reproductive mechanism that has the purpose of producing the widest range of individual variations in the species. Whether or not sex is "intrinsically" a reproductive process (Beukeboom - Perrin 2014, 5), it is in any case cause and outcome of the evolution according to the principle of natural and sexual selection. That inevitably leads us to Darwin, who placed sexual difference at the core of evolutionary biology. Since Darwin onward, sexual difference has abandoned the rigid substantialism of two immutable and eternal essences in order to gain the plasticity of a vital matter entangled in the environment and time. Inspired by Darwin's naturalism, some material authors have intended a certain alliance between evolutionary theory and material ontologies, with the result of a contemporary "evolutionary imperative" (Alaimo - Hekman 2008, 53), convergent with the tenet of self-differing progress.

Elizabeth Grosz, for example, considers Darwin's evolutionary naturalism to prefigure the ontology of sexual difference (Grosz 2004, 10). Grosz traduces Darwinian evolution in the ontological terms of pure difference so that natural life becomes itself by distinguishing, rendering more and more distinct, specializing and adapting to always new conditions (Grosz 2004, 46). Given that life is a continuum process of differing, there is not a clear and distinct fact whose sudden occurrence turns inorganic into organic beings, not-alive into living matter, matter into consciousness or nature into culture. Contrary, reality comprises a complex and progressive transition whose gradualness resists all clear delimitation and forces to establish similarities and continuities everywhere. Although Darwin ignored genetic mechanisms or cellular symbiosis, the framework of his evolutionary progress remains the framework of new material approaches to natural life.

The continual differing of all living being overcomes the dualism of two sexes mutually exclusive and opposed as the active to the passive, the rational to the material, the cultural to natural, etc. According to the dialectics of difference man and woman are both active and creative energies, assemblages of complex and heterogeneous elements. Even Darwin, a century and a half ago, alluded to the rudimentary presence of one sex into the other on the grounds of evolutionary monogenesis and continuity (Darwin 1981, 207-8). Between them, there are so many contrasts as similarities and continuities. In consequence, sexual dimorphism turns to be much more diverse, disseminated and reticular than the oversimplified representation of two opposite sexes (cf. Wilson 2004, 58-59; Fausto-Sterling 2000, 30 ff.; Richardson 2013, 197 ff.). 
One of the hallmarks of sexual dualism has been the myth of brain sex. In fact, the brain's size, weight, lateralization or hormones have been argued to justify the mental inferiority and political subordination of women. Although the myth has been largely deconstructed by Feminist theory and dualistic interpretations of the male and female brain seem to be overcome, however, neurobiology continues investigating sexual differences actually in women's and men's brains. On the one hand, scientists agree that "bodies matter - genes matter, hormones matter, brains matter. But how?” (Jordan-Young 2010, 20). On the other hand, they disagree about how and how much the brain expresses sexual differences (Nelson 2017, 172-4).

It is commonly assumed by neurosciences that the exposure to androgens and estrogens in the prenatal period produces in some areas of the brain sex differences in structure, density, volume, functions or wiring. Many differences are most considerable in the prenatal period and diminish later. The brain transcribes genetic differences, expressed in turn by different behaviors, skills, interests, preferences or timing. But how? Recent scientific patterns have objected for a number of reasons the idea of a linear and irreversible hormone effects on brain circuits. First, brain developments depend on interactions with the environment, which prevents a linear unfolding and fosters its malleable adaptation to unstable contexts. Rebecca speaks of an "inseparable fusing" (Jordan-Young 2010, 286) between internal and external, innate and acquired factors, entangled into contingent developments. Second, due to the inner flexibility or plasticity of the brain itself, inconsistent with rigid bio-programs or fixed neuronal circuits. Far from an inexorable determinism, plasticity means, as Catherine Malabou asserts, that "humans make their own brain" (Malabou $2008,1)$. Lastly, because of the difficulties in finding the exact correspondence between genes and hormones, on the one hand, and behaviors or skills, on the other. However, despite these difficulties, most neuroscientific studies agree that women show advantages in verbal skills (including verbal memory), while men present advantages in spatial skills (spatial perception and three-dimensional mental rotation), gross motor force and aggressive tendencies (Wizemann Pardue 2001, 86; Buss - Malamuth 1996, 116 ff.).

In sum, neurobiological discussions on brain sex have abandoned the bias of a dualistic pattern in order to consider the heterogeneity and complexity of sexual differing, fraught with continuities and similarities. Female and male biology compose a mosaic of countless elements, reciprocally overlapped and intra-acted. There are sexual differences between individuals of other sex as well as between individuals of the same sex. Even more, recent scientific patterns have also abandoned the dualism between biological sex and social gender to propose instead a dialectical synthesis between nature and culture, genes and society. The environment and culture are wired in human biology, as 
well as biology and genetics are active in culture and society. Biology includes genes and hormones, but also cultural habits, environmental conditions and emotional dispositions. Therefore, far from being reduced to either biology or normative fiction, sexual difference constitutes a synergic reality integrated by physical, psychic, social, and existential forces.

According to new material ontologies, the matter is precisely that energy capable of producing material as well as immaterial effects like consciousness, mind and culture. Given that the matter here at stake is not-one and not-all, from its virtuality emerge also non-material realities. If, as Žižek asserts, "only materialism can accurately explain the phenomena of mind, consciousness, and so on" (Žižek 2006, 167), then it can be said, in the same respect, that only material sexual difference can explain the emergence of sexuality at psychic, cultural, and existential levels. One does not exist without the others.

The psychosomatic unity of human beings implies sexuality expanding all over the body, mind and culture, differing and moving the whole existence. The complex assemblage of sex does not have a control center but multiple forces converging on a single subject. Psychic and social energies are the other side of biological sex.

\section{Assembling Psychic Sexuation from Within}

The tenet of psychosomatic unity assumes that "differences are one and all physical and psychical” (Malabou 2008, 81), including sexual differences, which expand their own expression to subjective and social levels. According to Malabou, biological differences determine a sort of "proto-self" (Malabou 2008, $57 \mathrm{ff} ., 80$ ), the base of emerging psychic and spiritual phenomena. Psychic and spiritual sexuality differs from the biological one, that is, negates and transforms it into new non-material energies. Psychical forces such as affects, libido, consciousness, unconsciousness, desires, pleasure, enjoyment, fantasies, knowledge, etc. are sexed, so as is the body to they belong. I do not want to say here that these phenomena should respond to cultural stereotypes of gender, but rather that they are effects of sexual drives and plastic bodies.

Psychosomatic unity constitutes an essential material principle of new realisms and materialisms (Alaimo - Hekman 2008; Grosz 1994; Johnston 2013; 2014). They consider that matter produces interiority, so that "matter feels, converses, suffers, desires, yearns and remembers" (Rick Dolphijn - van der Tuin $2012,48)$. Such material intimacy is what the philosophical tradition named as psyche: the sentient and conscious "other" of the body, capable of becoming intentionally - everything. However, while philosophical tradition understood the soul as the immaterial form and vital principle of the body, new material 
ontologies comprehend it as a sexual drive emerging from the morphogenetic capacities of matter itself.

Having attained this point, it is significant to distinguish psychic sexuation from anatomical determinism of sexes as well as from the cultural relativism of genders. In the first case, the body is considered a passive substratum for eternal and immutable forms, determinants of sex's behavior and stereotypes. In the second case, the body is equally the passive recipient of discursive constructions, radically contingent and historical. By contrast, from our perspective, neither biology has to do with a passive and meaningless matter formed by eternal essences, nor culture has to do with an abstract system of arbitrary norms. Both biology and culture respond to synergic material paradigms, that includes psychic sexuality. It involves multiple microforces, inner and outer and expresses a plastic and open process throughout life-time.

From the psychic point of view, sexual differing synthesizes heterogeneous elements such as physical sexual characters and dispositions, unconscious drives, fantasies, affects, socio-cultural structures, collective imaginary, personal experiences and choices, both conscious and unconscious, innate and acquired, fraught with tensions and contradictions. If it was Darwin who introduced the relevance of sexual difference for the evolution of life, it was Sigmund Freud who highlighted the relevance of sexuality for psychical development and ontogenetic evolution. According to Freud, sexuality is irreducible to a genital function or an instinctual mechanism determined by a rigid behavioral program. On the contrary, sexual drive or libido comprises the vital energy of the whole human being (Freud 2017, 2015; De Lauretis 2008), his dynamic, open, multiple drives to live.

Following Freud, other psychoanalysts like Slavoj Žižek, Alenka Zupančič or Joan Copjec consider psychic sexuation as an ontological constitutive of human identity irreducible to sociolinguistic norms or imaginary signifiers (Žižek 2019, 2017; Zupančič 2017; Copjec 2015). Even if cultural representations of femininity and masculinity are one of the forces conforming psychical sexual identity, they just act along with many other elements and drives, conscious and unconscious. One can adjust or reject social stereotypes without leaving her sexual difference, plastic enough to keep differing throughout life. This is why for Žižek, Zupančič or Copjec sexual difference remains a "rest" outside any signifiers, a "Real" dynamism behind any representation, a "negative" drive breaking and transforming any fix identification, whatever it may be. Instead of an all and complete given identity, sexual difference remains the "not-all" and "not-one" of all psychic identity.

As an ontological reality, psychic sexual difference expresses a negative determination rather than a fixed and immutable affirmation. The differing here at stake implies incompleteness, inconsistency, indetermination and antagonism 
(Žižek 2019, 51) instead of completeness and stability. As the formative force of subjectivity, sexual difference operates in two fundamental ways, namely: as a negative limit to the narcissistic and omnipotent "I am all", and as relational otherness constitutive of the subject. Sexual difference imposes a real other to infantile narcissism, produces a gap in the subject and opens the possibility of being-two as a proper field for the human community. At a last resort, it must be stated that psychic sexuation supposes socialization to the extent that opens the room for another and others.

The ontological consideration of sexual difference along with the reconsideration of difference as a self-differing dynamism allows to overcome the dualist social imaginary between a passive, castrated, and envious woman as opposed to an active, rational, and envied man. According to the logic of not-all, sexuation is not about "the contradiction between 'opposite' sexes, but the contradiction inherent to both, 'barring' them both from within" (Zupančič 2017, 72). All subject - male or female - remains not-all, self-different, that is, mediated by another, so the sexual difference starts at once the social community.

Given that sexuality does not represent an immovable psychic property but a dynamic and heterogeneous process expanded and embedded all over the body and mind, then one might say that there are multiple micro-sexualities unified by each singular subject. Following the economy of differing, Elizabeth Grosz and Elspet Probyn speak of "petty sexualities" (Grosz - Probyn 1995, x) capable of unfolding, overlapping and transforming libidinal flows in constant circulation. Since difference means differing, sex implies "the sexualization of memory, of departures and dislocations, of writing and collaboration, of urban movement, of skin and surfaces, of silken ties, of mouthing words, of singing, of eating, obsessively collecting, of conquering and imaging" (Grosz - Probyn $1995, \mathrm{x})$. Also in this respect, the not-one of sexual differing makes room to the entire world as its own other.

Ultimately, there is another level of sexual difference referred to the last synthesis in which the subject recognizes himself as a free and singular. One might call it the spiritual level of sexual difference, meaning by the spirit rather than an entelechy coming from the eternal world, the free self-consciousness emerging from a material sexed subject. The spiritual instantiation of sexual differing expresses the free choice of being this not-all individual, embodied, finite and temporal. It would be another form of dualism to assume freedom or spirit as a kind of neutral or asexual entity floating around. They must be assumed, by contrast, as the ultimate determination by which sexual differing constitutes a humane person, singular and unique, actualizing his identity in an unrepeatable way.

The free spirit is also a sexual drive able to synthesize the entire person and make it transparent to itself. Such a free and transparent energy expresses 
what, in other terms, Luce Irigaray named as the "transcendental" dimension of sexual differing (Irigaray - Marder 2016, 5; Irigaray 2017, 4-5), meaning that instance in which living matter spreads the subjective, social and cultural field of human existence. Spirit is not-all and not-one either, whence it becomes, differs, is two (Irigaray 2000,29). Precisely because spirit is never one, all, pure clarity, but always uncertain, incomplete, finite, unconscious, the subject has to choose. Being-two, differing, becoming-other is properly the spiritual act of sexual difference.

\section{To Conclude: Sexual Differing as Political Praxis}

The principal purpose of these pages has been to approach sexual difference as an overcoming concept of both biological determinism of sexes and sociolinguistic culturalism of gender. By conceptual difference we interpreted a negative and reflective self-movement; by sexuality, a vital and material energy pervading all activity and field. Sexual differing means then an ontological condition of the human subject, its inherent antagonism, gap, contradiction. Because of sexual difference, the not-one is open to another. The ontological difference replaces the homo-logic of the One and All perfect substance by the hetero-geneity of being-two, not-All, a fractured and incomplete subject in a constant transformation. Such differing crosses all physical, psychic, social and spiritual fields, each of which involves multiple microforces reciprocally related and synthetically unified by the personal existence.

Sexual difference constitutes a material reality encrypted, embedded and expanded in the flesh. According to new materialisms, matter feels, desires, suffers, desires, thinks, etc., hence the ascent of sexuality from biological to subjective and cultural material energies. Nature and culture, body and spirit, genes and history are reciprocally intra-acted in the framework of multiple and complex assemblages. To represent them as abstract, independent and opposite terms would miss the mark of complex and synergic paradigms to return to old dualisms. Contrary to dualism, the principle of sexual differing removes conventional stereotypes in order to enable renewed senses.

Ultimately, sexual differing intrinsically implies a political conception to the extent that the human other belongs to the relational and reciprocal dynamism of sexed subjects. In consequence, that conceptualization supposes a political project tending to undermine the patriarchal structures based on the supreme One/All, and recreating open, plastic and plural institutions instead. A politics of differing supposes some main principles like, for example, the principle of being-two, always other, consistent with the principle of relational subjects reciprocally engaged. Second, the politics of a living and affective 
matter in constant openness, entitled to free expansion and circulation. Third, a culture in which fractures, contradictions, and tensions play a game never over.

If sexual difference is not the sum of abstract representations, but the self-creative dynamism of free subjects, then it contains the full potential for further political transformations.

\section{References}

ALAIMO, S. - HEKMAN, S. (2008): Material Feminisms. Bloomington: Indiana University Press.

BADIOU, A. (2017): The True Life. Cambridge: Polity Press.

BATTERSBY, C. (1998): Phenomenal Woman. Feminist Metaphysics and the Patterns of Identity. New York: Routledge.

BEUKEBOOM, L. - PERRIN, N. (2014): The Evolution of Sex Determination. Oxford: Oxford University Press.

BLUHM, R. - MAIBOM, H. L. - JACOBSON, A. J. (2012): Neurofeminism. Issues at the Intersection of Feminist Theory and Cognitive Sciences. New York: Palgrave Macmillan.

BRAIDOTTI, R. (2006): Transpositions: On Nomadic Ethics. Cambridge: Polity Press.

BRAIDOTTI, R. (2002): Metamorphoses: Towards a Materialist Theory of Becoming. Cambridge: Polity Press.

BRAIDOTTI, R. (1994): Nomadic Subjects: Embodiment and Sexual Difference in Contemporary Feminist Theory. New York: Columbia University.

BUSS, D. M. - MALUMUTH, N. (1996): Sex, Power, Conflict. Evolutionary and Feminist Perspectives. Oxford: Oxford University Press.

BUTLER, J. (2004): Undoing Gender. New York: Routledge.

BUTLER, J. (1999): Gender Trouble. Feminism and the Subversion of Identity. New York: Routledge.

BUTLER, J. (1993): Bodies that Matter. On the Discursive Limits of 'Sex'. New York: Routledge.

COLEBROOK, C. - BUCHANAN, I, (2000): Deleuze and Feminist Theory. Edinburgh: Edinburgh University Press.

COOLE, D. - FROST, S. (2010): New Materialisms: Ontology, Agency, and Politics. Durham \& London: Duke University Press.

COPJEC, J.(2002): Imagine There's no Woman: Ethics and Sublimations. Cambridge \& London: The MIT Press.

DARWIN, C. (1981): The Descent of Man and Selection in Relation to Sex. Princeton \& New Jersey: Princeton University Press.

DE LAURETIS, T. (2008): Freud's Drive. Psychoanalys, Literature and Film. New York: Palgrave Macmillan.

DELEUZE, G. - GUATTARI, F. (1994): What is Philosophy? New York: Columbia University Press.

DOLPHIJN, R. - VAN DER TUIN, I. (2012): New Materialism: Interviews and Cartographies. Michigan: Open Humanities Press. 
FAUSTO-STERLING, A. (2000): Sexing the Body. Gender Politics and the Construction of Sexuality. New York: Basic Books.

FREUD, S. (2017): Three Essays on the Theory of Sexuality. London \& New York: Verso.

FREUD, S. (2015): Beyond the Pleasure Principle. New York: Dover Publications.

FREUD, S. (1955): The Psychogenesis of a Case of Homosexuality in a Woman. London: Hogarth Press.

GATENS, M. (1996): Imaginary Bodies: Ethics, Power and Corporeality. London: Routledge.

GRATTON, P. (2014): Speculative Realism: Problems and Prospects. London \& New York: Bloomsbury.

GROSZ, E. (2011): Becoming undone: Darwinian Reflexion on Life, Politics, and Art. Durham \&London: Duke University Press.

GROSZ, E. (2004): The Nick of Time: Politics, Evolution and the Untimely. Crows Nest: Allen \& Unwin.

GROSZ, E. - (1995): Space Time, and Perversion. Essays on the Politics of Bodies. New York \& London: Routledge.

GROSZ, E. - (1994): Volatile Bodies. Toward a Corporeal Feminism. Bloomington \& Indianapolis: Indiana University Press.

GROSZ, E. - PROBYN, E. (1995): Sexy Bodies. The Strange Carnalities of Feminism. New York: Routledge.

HEGEL, G. W. F. (2010): The Science of Logic. New York: Cambridge University Press. HEGEL, G. W. F. (1979): Phenomenology of Spirit. Oxford: Oxford University Press.

IRIGARAY, L. (2017): To Be Born. Genesis of a New Human Being. Macmillan Palgrave.

IRIGARAY, L. (2000): Democracy Begins Between Two. London: The Athlone Press. IRIGARAY, L. (1996): I Love to You. Sketch for a Felicity within History. New York: Routledge.

IRIGARAY, L. (1993): Ethics of Sexual Difference. Ithaca: Cornell University Press.

IRIGARAY, L. (1985a): Speculum of the Other Woman. New York: Cornell University Press.

IRIGARAY, L. (1985b): This Sex which is not One. Ithaca: Cornell University Press.

IRIGARAY, L. - MARDER, M. (2016): Through Vegetal Being: Two Philosophical Perspectives. New York: Columbia University Press.

JOHNSTON, A. (2014): Adventures in Transcendental Materialism. Dialogues with Contemporary Thinkers. Edinburgh: Edinburgh University Press.

JOHnSTON, A. (2013): Prolegomena to Any Future Materialism. Volume One: The Outcome of Contemporary French Philosophy. Evanston: Northwestern University Press.

JORDAN-YOUNG, R. M. (2010): Brain Storm. The Flaws in the Science of Sex Differences. Cambridge \& London: Harvard University Press.

MALABOU, C. (2016). Before Tomorrow. Epigenesis and Rationality. Cambridge: Polity Press.

MALABOU, C. (2012): The New Wounded. From Neurosis to Brain Damage. New York: Fordham University Press. 
MALABOU, C. (2008): What Should We Do with Our Brain? New York: Fordham University Press.

MALABOU, C. (2005): The Future of Hegel. Plasticity, Temporality and Dialectic. New York: Routledge.

NANCY, J-L. (1993): The Birth to Presence. Stanford: Stanford University Press.

NELSON, L. H. (2017): Biology and Feminism: A Philosophical Introduction. New York: Cambridge University Press.

PARISI, L. (2004): Abstract Sex. Philosophy. Biotechnology and the Mutations of Desire. London \& New York: Continuum.

PRECIADO, B. P. (2003): Multitudes Queer: note pour une politique des anormaux. In: Multitudes 2 (12), 17-25.

RICHARDSON, S. S. (2013): Sex Itself. The Search for Male \& Female in the Human Genome. Chicago \& London: University of Chicago Press.

STONE, A. (2002): Luce Irigaray and the Philosophy of Sexual Difference. New York: Cambridge University Press.

VAN DER TUIN, I. (2014): Generational Feminism: New Materialist Introduction to a Generative Approach. New York: Lexington Books.

WILSON, E. A. (2004): Psychosomatic. Feminism and the Neurological Body. Durham \& London: Duke University Press.

WIZEMANN, T. M. - PARDUE, M. L. ( 2001): The Biological Contributions to Human Health Does Sex Matter. Washington: Institute of Medicine.

ŽIŽEK, S. (2019): Sex and the Failed Absolute: Capital of Fashion. London \& New York: Blomsbury,

ŽIŽEK, S. (2017): Incontinence of the Void. Economico-Philosophical Spandrels. Cambridge \& London: The MIT Press.

ŽIŽEK, S. (2016): Disparities. London \& Oxford: Bloomsbury.

ŽIŽEK, S. (2006): The Parallax View. Cambridge \& London: The MIT Press.

ZUPANČIČ, A. (2017): What is Sex? Cambridge \& London: MIT Press.

\section{María J. Binetti, PhD.}

Instituto Interdiciplinario de Estudios de Género

Facultad de Filosofía y Letras, Universidad de Buenos Aires

Puan 480, Ciudad Autónoma de Buenos Aires, C1406CQJ

Argentina

CONICET (National Council for Scientific and Technical Research) Godoy Cruz 2290, Ciudad Autónoma de Buenos Aires, C1425FQB Argentina 